Samad

Indonesia

\title{
The Development of a Home Cognitive Stimulation Package for 2-3-Year-Old Children
}

DOI: 10.15804/tner.2019.55.1.17

\begin{abstract}
The presented study aimed to develop a cognitive stimulation package for 2-3-year-old children and examine the effectiveness of the product in facilitating children's cognitive development at home. The study consisted of six phases, namely analysis, design, prototype development, formative evaluation, implementation, and summative evaluation. The analysis phase of this study involved 147 mothers and 3 experts. The participants in the formative evaluation phase consisted of 10 mothers, while the participants in the implementation and summative evaluation stages consisted of 20 mothers. The results of the experts' and target users' assessments suggest that the cognitive stimulation package developed in this study is valid and practical. In addition, the stimulation package has also been proven effective in facilitating the cognitive development of 2-3-year-old children at home.
\end{abstract}

Keywords: cognitive stimulation, childcare, children's games

\section{Introduction}

A number of studies have reported substantial contribution of the environment to children's cognitive development (Grantham-McGregor et al., 2007; Zheng, Rijsdijk, \& Arden, 2018). Family is closest to children. Parents, especially mothers, serve as the main actor who is responsible for children's care and protection at 
home. Mc Coy et al. (2018) assert that it is important for parents to surround their children with adequate stimulation. If the stimulation process does not occur adequately, children's cognitive growth may be hindered. Consequently, children's potentials cannot develop optimally (Walker, Wachs, Gardner, Lozoff, et al., 2007).

The empirical proof has underlined the importance of cognitive stimulation at home, especially in facilitating children's cognitive development at their first three years of life. Therefore, a conceptual framework can be built based on the assumption that a home environment, which surrounds children during the first three years of their life, could affect the children's cognitive growth. Home environment which is closest to the children needs modification so that adequate stimulation can be provided to assist children in developing their cognitive ability. Mothers, who play a major role in childcare, are required to possess sufficient skills to conduct positive activities to stimulate their children's cognitive development. Likewise, the findings of Ambarwati, Yahya, \& Sutanto (2015) suggest that exemplary parenting skills will help parents carry out their responsibilities accurately, which results in proper growth of potentials in children.

Cognitive stimulation provided in early childhood should not be filled with mere knowledge, as in the case of adult education. Instead, children need to be given a lot of opportunities to explore their surrounding world through their senses so that they can recognize, distinguish, compare, and feel what lies in front of them or what exists in the environment. Accordingly, as summarized by Khadijah (2016), auditory, visual, kinesthetic, tactile, arithmetic, and geometric stimulation is imperative.

Interventions to the provision of cognitive stimuli for children need to be designed. Several efficacy tests and program evaluations have proven the benefits of home visiting strategies and/or center-based training, including efforts to improve mothers' skills and knowledge for children's development (Walker, 2010). Based on that, the presented study was intended to develop a cognitive stimulation package for 2-3-year-old children.

\section{$\underline{\text { Research Methodology }}$}

The study was designed as a Research and Development study employing the Content Development Process (CDP). It was conducted at six stages, i.e., analysis, design, prototype development, formative evaluation, product implementation, and summative evaluation (Gustafson, 1981). The detailed design of the research is presented in Table 1. 
Table 1. The phases and subjects of the research

\begin{tabular}{|c|c|c|c|}
\hline Phase & Aim & Research Activities & $\begin{array}{l}\text { Research } \\
\text { Subject }\end{array}$ \\
\hline Analysis & To analyze data & Distribute the questionnaire & 147 mothers \\
\hline Design & $\begin{array}{l}\text { To generate a cog- } \\
\text { nitive stimulation } \\
\text { package }\end{array}$ & $\begin{array}{l}\text { Perform theoretical and task analyses to } \\
\text { determine the structure of the package, } \\
\text { identify ideas for stimulation activities, } \\
\text { materials/tools that are needed as well as } \\
\text { methods to prepare the materials or carry } \\
\text { out the activities }\end{array}$ & \\
\hline $\begin{array}{l}\text { Prototype } \\
\text { Development }\end{array}$ & $\begin{array}{l}\text { To produce an } \\
\text { initial prototype } \\
\text { of the package }\end{array}$ & $\begin{array}{l}\text { Organize various ideas for stimulation } \\
\text { activities and arrange them in the form of } \\
\text { a package }\end{array}$ & \\
\hline \multirow[b]{2}{*}{$\begin{array}{l}\text { Formative } \\
\text { Evaluation }\end{array}$} & $\begin{array}{l}\text { To generate } \\
\text { a valid prototype } \\
\text { of the package }\end{array}$ & Invite experts to validate the package & 3 experts \\
\hline & $\begin{array}{l}\text { To generate } \\
\text { a practical } \\
\text { prototype of the } \\
\text { package }\end{array}$ & Conduct a test on target audience & 10 mothers \\
\hline $\begin{array}{l}\text { Product Imple- } \\
\text { mentation }\end{array}$ & $\begin{array}{l}\text { To try out the } \\
\text { valid and practical } \\
\text { package }\end{array}$ & $\begin{array}{l}\text { Parents implemented stimulation activities } \\
\text { in the package on their children }\end{array}$ & 20 mothers \\
\hline $\begin{array}{l}\text { Summative } \\
\text { Evaluation }\end{array}$ & $\begin{array}{l}\text { To generate an } \\
\text { effective cogni- } \\
\text { tive stimulation } \\
\text { package }\end{array}$ & $\begin{array}{l}\text { Analyze the accomplishment of the target } \\
\text { level of the children's cognitive development } \\
\text { (before and after accepting the stimulation) }\end{array}$ & 20 children \\
\hline
\end{tabular}

The participants in the analysis phase consisted of 147 mothers, who were selected in a purposive way. The formative evaluation phase involved 10 mothers, while the implementation phase involved 20 mothers, who were randomly selected from a group of mothers who had a 2-3-year-old child. The summative evaluation subject consisted of 20 children, who had received stimulation.

To answer the research problems, a questionnaire and a checklist were designed. The questionnaire contained 30 open-ended statements with four alternative answers, which referred to the theories and previous research findings related to children's cognitive development, such as Brooks, (2011); Khadijah (2016); and the Ministry of Education (2007). The questionnaire that was used to collect the experts' responses on the prototype consisted of 35 items. These items covered the 
aspects of the development foundation, language, the appropriateness of the stimulation, children's cognitive development stages, and the characteristics or principles of the stimulation program. The questionnaire used to examine the validity of the checklist consisted of 4 items. These items helped the experts (validators) examine the clarity of the instructions, the conformity of cognitive development indicators with children's cognitive ability that was going to be evaluated, and the conformity of stimulation purposes with the activities. The target audience responses were collected using a questionnaire that elicited the readability, appeal, and clarity of the instructions, and the safety of the package used during the stimulation process. The checklist used consisted of indicators of the cognitive development of children aged 2-3 years (Ministry of Education, 2002).

The effectiveness of the package was evaluated through the difference found in the children's cognitive achievement. The difference was interpreted using $\mathrm{N}$-gain analysis and then categorized into one of the following criteria: low $(0.00<$ $\mathrm{g}<0.30)$; medium $(0.30 \leq \mathrm{g}<0.70)$; high $(0.70 \leq \mathrm{g} \leq 1)$. The significance of the difference between the children's cognitive achievement before and after the intervention was examined through hypotheses testing and paired sample t-test analysis.

\section{Research Findings}

\section{Needs Analysis for the Development of the Child's Cognitive Stimulation Package}

The data collected show that the participants had a low awareness of what was needed to promote the child's cognitive development $(66.67 \%$ were in the low category and $33.33 \%$ were in the high category). The findings related to the aspects of the child's cognitive development are presented in Table 2.

Table 2. Mothers' awareness of the aspects of cognitive development

\begin{tabular}{lcccccc}
\hline & Auditory & Visual & Kinesthetic & Tactile & Arithmetic & Geometric \\
\hline Mean & 19.05 & 9.97 & 13.64 & 7.41 & 7.80 & 14.71 \\
\hline Median & 19 & 10 & 13 & 7 & 7 & 14 \\
\hline Mode & 18 & 10 & 12 & 6 & 7 & 15 \\
\hline
\end{tabular}




\section{The Description of the Child's Cognitive Stimulation Package}

In the prototype development phase, two units were generated, a guidance book and a manual. The details of this two-unit package are shown in Table 3.

Table 3. The descriptions of the child's cognitive stimulation package

\begin{tabular}{|c|c|c|}
\hline Unit & Components & Content \\
\hline \multirow{7}{*}{$\begin{array}{l}\text { The Cognitive } \\
\text { Stimulation } \\
\text { Guidance Book }\end{array}$} & Rationale & $\begin{array}{l}\text { The empirical proof of parents' role as the main supporter } \\
\text { of their children's cognitive development }\end{array}$ \\
\hline & $\begin{array}{l}\text { Supporting } \\
\text { theory }\end{array}$ & $\begin{array}{l}\text { The explanations of children's cognitive development } \\
\text { theories }\end{array}$ \\
\hline & Benefits & The explanations of the activities in the package \\
\hline & Impacts & An overview of the child's cognitive achievement \\
\hline & Specifications & $\begin{array}{l}\text { The explanations of the direction and scope of ideas in the } \\
\text { package }\end{array}$ \\
\hline & Strengths & Information on the strengths of the package \\
\hline & Instructions & $\begin{array}{l}\text { An overview of activities performed to accomplish the } \\
\text { stimulation process }\end{array}$ \\
\hline \multirow{3}{*}{$\begin{array}{l}\text { The Cognitive } \\
\text { Stimulation } \\
\text { Manual }\end{array}$} & Package 1 & \multirow[t]{3}{*}{ Each contains 11 stimulation activities } \\
\hline & Package 2 & \\
\hline & Package 3 & \\
\hline
\end{tabular}

\section{Validity and Practicality of the Child's Cognitive Stimulation Package}

The results of the experts' validation and a test administered to the target users showed that the initial package prototype was very valid (3.41) and very practical (3.58). The findings on the validity and practicality of the initial package prototype are presented in Tables 4 and 5 .

Table 4. The results of the validity test

\begin{tabular}{clll}
\hline No. & \multicolumn{1}{c}{ Aspect } & Average & Criteria \\
\hline 1 & The foundation of the product development & 3.29 & Very Valid \\
\hline 2 & Language & 3.33 & Very Valid \\
\hline 3 & $\begin{array}{l}\text { The conformity of the package to the 2-3-year-old child's } \\
\text { cognitive development needs }\end{array}$ & 3.46 & Very Valid \\
\hline 4 & $\begin{array}{l}\text { The conformity of the package to the 2-3-year-old child's } \\
\text { cognitive development stages }\end{array}$ & 3.43 & Very Valid \\
\hline 5 & $\begin{array}{l}\text { The conformity of the package to the 2-3-year-old child's } \\
\text { stimulation program characteristics }\end{array}$ & 3.33 & Very Valid \\
\hline
\end{tabular}




\begin{tabular}{clccc}
\hline No. & \multicolumn{1}{c}{ Aspect } & Average & Criteria \\
\hline 6 & $\begin{array}{l}\text { The conformity of the package to the principles of the } \\
2-3 \text {-year-old child's stimulation program development }\end{array}$ & 3.67 & Very Valid \\
\hline Total & & 3.41 & Very Valid \\
\hline
\end{tabular}

Table 5. The results of the practicality test

\begin{tabular}{clcc}
\hline No. & \multicolumn{1}{c}{ Aspect } & Average & Criteria \\
\hline 1 & The font size is proportional and visible & 4.00 & Very Practical \\
\hline 2 & The font type is appropriate so the content is readable & 4.00 & Very Practical \\
\hline 3 & The layout is in harmony & 3.80 & Very Practical \\
\hline 4 & The color is well-selected and it helps clarify the content & 3.40 & Very Practical \\
\hline 5 & The appearance is attractive & 3.60 & Very Practical \\
\hline 6 & The sentences are understandable & 3.30 & Very Practical \\
\hline 7 & $\begin{array}{l}\text { It is easy to understand the methods of preparing the envi- } \\
\text { ronment for play }\end{array}$ & 3.40 & Very Practical \\
\hline 8 & $\begin{array}{l}\text { It is easy to understand the methods of playing or the } \\
\text { instructions to play }\end{array}$ & 3.50 & Very Practical \\
\hline 9 & It is easy to prepare the environment for play & 3.20 & Practical \\
\hline 10 & It is easy to provide the proposed stimulation & 3.00 & Practical \\
\hline 11 & The materials/tools used are easy to find & 4.00 & Very Practical \\
\hline 12 & The materials/tools used are safe for children & 3.70 & Very Practical \\
\hline 13 & The stimulation is safe for children & 3.70 & Very Practical \\
\hline Total & & 3.58 & Very Practical \\
\hline
\end{tabular}

\section{The Effectiveness of the Child's Cognitive Stimulation Package}

The children's cognitive achievement after receiving cognitive stimulation from their mothers is presented in Table 6.

Table 6. The cognitive achievement of the 2-3-year-old children

\begin{tabular}{|c|c|c|c|c|c|}
\hline Indicator & Data & Scores & Gain & N-Gain & $\begin{array}{c}\text { Interpre- } \\
\text { tation }\end{array}$ \\
\hline \multirow{2}{*}{$\begin{array}{l}\text { Able to mention surrounding } \\
\text { objects }\end{array}$} & Pretest & 22.50 & \multirow[t]{2}{*}{14.00} & \multirow[t]{2}{*}{0.80} & \multirow[t]{2}{*}{ High } \\
\hline & Post-test & 36.50 & & & \\
\hline \multirow{2}{*}{$\begin{array}{l}\text { Able to classify similar } \\
\text { objects }\end{array}$} & Pretest & 25.50 & \multirow[t]{2}{*}{12.50} & \multirow[t]{2}{*}{0.86} & \multirow[t]{2}{*}{ High } \\
\hline & Post-test & 38.00 & & & \\
\hline
\end{tabular}




\begin{tabular}{|c|c|c|c|c|c|}
\hline Indicator & Data & Scores & Gain & N-Gain & $\begin{array}{c}\text { Interpre- } \\
\text { tation }\end{array}$ \\
\hline \multirow{2}{*}{$\begin{array}{l}\text { Able to classify objects with } \\
\text { circular shape }\end{array}$} & Pretest & 25.50 & \multirow[t]{2}{*}{12.00} & \multirow[t]{2}{*}{0.83} & \multirow[t]{2}{*}{ High } \\
\hline & Post-test & 37.50 & & & \\
\hline \multirow{2}{*}{$\begin{array}{l}\text { Able to classify objects with } \\
\text { square shape }\end{array}$} & Pretest & 23.50 & \multirow[t]{2}{*}{13.50} & \multirow[t]{2}{*}{082} & \multirow[t]{2}{*}{ High } \\
\hline & Post-test & 37.00 & & & \\
\hline \multirow{2}{*}{$\begin{array}{l}\text { Able to differentiate sizes: big } \\
\text { and small }\end{array}$} & Pretest & 23.50 & \multirow[t]{2}{*}{14.00} & \multirow[t]{2}{*}{0.85} & \multirow[t]{2}{*}{ High } \\
\hline & Post-test & 37.50 & & & \\
\hline \multirow[t]{2}{*}{ Able to distinguish sounds } & Pretest & 23.50 & \multirow[t]{2}{*}{12.50} & \multirow[t]{2}{*}{076} & \multirow[t]{2}{*}{ High } \\
\hline & Post-test & 36.00 & & & \\
\hline \multirow[t]{2}{*}{ Able to distinguish flavors } & Pretest & 22.00 & \multirow[t]{2}{*}{13.00} & \multirow[t]{2}{*}{0.72} & \multirow[t]{2}{*}{ High } \\
\hline & Post-test & 35.00 & & & \\
\hline \multirow[t]{2}{*}{ Able to distinguish scents } & Pretest & 22.00 & \multirow[t]{2}{*}{15.50} & \multirow[t]{2}{*}{0.86} & \multirow[t]{2}{*}{ High } \\
\hline & Post-test & 37.50 & & & \\
\hline \multirow{2}{*}{$\begin{array}{l}\text { Able to repeat/count num- } \\
\text { bers } 1-5 \text { (without recogniz- } \\
\text { ing the concept) }\end{array}$} & Pretest & 22.50 & \multirow[t]{2}{*}{13.50} & \multirow[t]{2}{*}{0.77} & \multirow[t]{2}{*}{ High } \\
\hline & Post-test & 36.00 & & & \\
\hline \multirow{2}{*}{$\begin{array}{l}\text { Able to classify at least } 2 \\
\text { colors }\end{array}$} & Pretest & 22.00 & \multirow[t]{2}{*}{17.00} & \multirow[t]{2}{*}{0.94} & \multirow[t]{2}{*}{ High } \\
\hline & Post-test & 39.00 & & & \\
\hline \multirow[t]{2}{*}{ Total } & Pretest & 232.50 & \multirow[t]{2}{*}{137.50} & \multirow[t]{2}{*}{0.82} & \multirow[t]{2}{*}{ High } \\
\hline & Post-test & 370.00 & & & \\
\hline
\end{tabular}

The effectiveness of the package in supporting the children's cognitive development is presented in Table 7.

Table 7. The effectiveness of the stimulation package in supporting the 2-3-year-old children's cognitive development

\begin{tabular}{|c|c|c|c|c|c|c|c|c|}
\hline & \multicolumn{5}{|c|}{ Paired Differences } & \multirow{3}{*}{$\mathrm{t}$} & \multirow{3}{*}{$\mathrm{df}$} & \multirow{3}{*}{$\begin{array}{c}\text { Sig. } \\
\text { (2-teiled) }\end{array}$} \\
\hline & \multirow[t]{2}{*}{ Mean } & \multirow{2}{*}{$\begin{array}{l}\text { Std. } \\
\text { Devia- } \\
\text { tion }\end{array}$} & \multirow{2}{*}{$\begin{array}{l}\text { Std. } \\
\text { Error } \\
\text { Mean }\end{array}$} & \multicolumn{2}{|c|}{$\begin{array}{l}\text { 95\% Confidence } \\
\text { Interval of thte } \\
\text { Difference }\end{array}$} & & & \\
\hline & & & & Lower & Upper & & & \\
\hline $\begin{array}{l}\text { Pair } 1 \text { Pretest - } \\
\text { Postest achieve- } \\
\text { ment of cognitive } \\
\text { development }\end{array}$ & -6.8750 & 1.4037 & .3139 & -7.5320 & -6.2180 & -21.903 & 19 & .000 \\
\hline
\end{tabular}




\section{Discussion}

\section{Needs for the Development of the Child's Cognitive Stimulation Package}

The research finding presented in the earlier section has shown that there are a number of mothers who are not fully aware of their children's needs to develop their cognitive ability. Therefore, there is a chance that the children may receive minimum cognitive stimulation as they grow. This result is in line with that found by Grantham-McGregor et al. (2007), who stated that many children under five years of age in the developing countries were exposed to various risks that could affect their cognitive development. As stated by Balck et al. (2017), affordable activities that can be done at home, such as story-telling, singing, playing with the household stuff are able to provide children with experiences that encourage their early development stages. Similarly, Dauch, Imwalle, Ocasio, \& Metz (2018) point out that parents need to pay attention to the following aspects of home environment: influences from individuals surrounding the children, sensory stimulation, objects, as well as the playground flexibility and safety.

Therefore, it is necessary to design an intervention to improve the motherchildren interactions that can support children's cognitive development because in Indonesian contexts research in cognitive domain is mainly focused on adult learners (Sultan, Rofiuddin, Nurhadi, \& Priyatni, 2017 \& 2018). The intervention design can be formulated in a guidance book of children's cognitive stimulation. In accordance with this finding, Black et al. (2017) state that there is an urgent need to increase mothers' participation in children's early stages of learning.

\section{The Characteristics of the Child's Cognitive Stimulation Package}

The child's cognitive stimulation package for 2-3-year-old children developed in this study has several characteristics:

First, stimulation is provided comprehensively. The significance of this comprehensive stimulation has been outlined by Baker-Henningham \& Boo (2010), who claim that the child's development is multidimensional; it covers the cognitive-language, sensory-motor, and socio-emotional domains, which are all dependent on each other. The substance of this characteristic is that each activity can stimulate more than one aspects of the child's development. This particular substance is illustrated in stimulation activities which are not oriented to the cognitive aspect only, but also to the combination of the sensory-motor activities that involve the child's motor skills and verbal interactions. The child's socio-emotional development.

Second, stimulation is provided based on age. Children entering this age group, according to Piaget, will encounter a conceptual thinking period or symbolic 
thinking, which allows them to construct simple concepts; they begin to classify objects into a particular group based on their similarity. The essence of this characteristic is that each stimulation activity is developed based on the 2-3-year-old child's cognitive growth. The stimulation activities involve the use of the child's sense and concrete objects. The activities also encourage the child to participate directly in them, so the stimulation focuses more on the process. As a result, the child is given an opportunity to obtain real learning experiences through various games that can help him/her to explore, manipulate, and respond to stimuli from the environment in a constructive way. As the child learns to organize the information she/he has collected, she/he will be more able to classify objects into a particular group based on their similarity (Piaget \& Inhelder, 1969).

Third, stimulation involves the mother's interaction as the main support of the child's play activities. Research findings that highlight the importance of the mother-child interaction in a stimulation process are reported by Jeon, Peterson, \& DeCoster (2013), who proved that parents' support is very beneficial for toddlers (aged 14 months or more) to develop their cognitive ability. In addition, a study showed that a relationship built earlier by the mother is the main agent that can determine the child's growth, which as a result influences the child's cognitive achievement in the future (Zeman, Cassano, Perry-Parrish, \& Stegall, 2006). The entity of this characteristic of stimulation has been designed to help mothers accompany their children to play so that the mother-child relationship can be established not only for the sake of the children's cognitive development, but also for their socio-emotional and physical-motor growth.

Fourth, the stimulation package guides mothers to provide stimulation for their children. The substance of this characteristic is that the stimulation package contains guidance for mothers as the target users to provide correct cognitive stimulation so that they are able to avoid errors that can harm the child's cognitive growth.

\section{The Effectiveness of the Child's Cognitive Stimulation Package}

The results of the $\mathrm{N}$-gain analysis showed that there was a difference in the children's cognitive achievement after receiving stimulation from the package developed in this study (gain $=137.50$ ). The gain scores of the children's cognitive achievement for all the indicators $(\mathrm{n}$-gain $=0.82$ ) were categorized as high $0.70 \leq \mathrm{g} \leq 1)$.

Statistical analysis of the effectiveness of the package showed t-calculated of 21.903 with sig. 0.0000 , hence Ho was rejected (sig. $<0.05$ ). Thus, it can be concluded that there is a significant difference between the children's early cognitive 
performance before the intervention and their cognitive achievement after receiving the intervention. In other words, the package has been proven effective in supporting the children's cognitive development.

According to these findings, it is obvious that the cognitive stimulation package developed in this study is effective in supporting the cognitive development of 2-3-year-old children at home. This effect is considered to result from the characteristics of the package that was designed comprehensively based on the characteristics of children aged 2-3 years. The comprehensiveness of the package also reflects the mother's role as the main supporter of her children's playing activities and as the main actor providing stimulation that does not limit children but allows them to pick their own toys and to receive compliments/awards/reinforcement.

The cognitive stimulation package developed in this study has been proven effective in supporting children's freedom to explore dominant parenting behaviors that are normally practiced in European and American families. Therefore, the stimulation package has potentials to be used widely to facilitate the cognitive development of children aged 2-3 years old at home.

\section{Conclusions}

The home cognitive stimulation package for 2-3-year-old children developed in this study is valid according to the experts and the target users. Empirically, this package has been reported effective in facilitating 2-3-year-old children's cognitive development. This stimulation package contains practical steps that can guide mothers to provide their children with positive cognitive stimulation. Therefore, it is strongly recommended for mothers to apply this cognitive stimulation package at home.

\section{Acknowledgments}

We would like to thank the Republic of Indonesia Ministry of Research, Technology, and Higher Education for the research grant. We would also like to acknowledge the reviewer, whose feedback was very insightful for us to improve the paper.

\section{References}

Ambarwati, E.R., Yahya, A.P., \& Sutanto, A.V. (2015). Level of Mother's Knowledge About Stimulation of Growth and Development in Children. Jurnal Kesehatan SAMODRA 
ILMU, 5(2). Retrieved from http://ejournal.stikes-yogyakarta.ac.id/index.php/jksi/ article/view/3

Baker-Henningham, H., \& Boo, F.L. (2010). Early Childhood Stimulation Interventions in Developing Countries: A Comprehensive Literature Review. Inter-American Development Bank and IZA, 71.

Black, M.M., Walker, S.P., Fernald, L.C.H., Andersen, C.T., DiGirolamo, A.M., Lu, C., ... Grantham-McGregor, S. (2017). Early childhood development coming of age: science through the life course. The Lancet; London, 389(10064), 77-90. http://dx.doi. org/10.1016/S0140-6736(16)31389-7

Brooks, J.B. (2011). The Process of Parenting. Rahmat Fajar Translation. Yogyakarta: Pustaka Pelajar.

Dauch, C., Imwalle, M., Ocasio, B., \& Metz, A.E. (2018). The influence of the number of toys in the environment on toddlers' play. Infant Behavior and Development, 50, 78-87. https://doi.org/10.1016/j.infbeh.2017.11.005

Grantham-McGregor, S., Cheung, Y.B., Cueto, S., Glewwe, P., Linda, R., \& Strupp, B. (2007). Child development in developing countries 1: Developmental potential in the first 5 years for children in developing countries. The Lancet; London, 369(9555), 60-70.

Gustafson, K.L. (1981). Survey of Instruksional Development Models. Eric Clearinghouse on Information Resources Syracuse University.

Jeon, H.-J., Peterson, C.A., \& DeCoster, J. (2013). Parent-child interaction, task-oriented regulation, and cognitive development in toddlers facing developmental risks. Journal of Applied Developmental Psychology, 34(6), 257-267. https://doi.org/10.1016/j. appdev.2013.08.002

Khadijah. (2016). Early Childhood Cognitive Development. Medan: Perdana Publishing.

McCoy, D.C., Salhi, C., Yoshikawa, H., Black, M., Britto, P., \& Fink, G. (2018). Homeand center-based learning opportunities for preschoolers in low- and middle-income countries. Children and Youth Services Review. https://doi.org/10.1016/j. childyouth.2018.02.021

Ministry of Educational. (2002). Reference Learning Menu at The Day Care Center. Jakarta: Directorate General of Out of School Education and Youth of the Ministry of National Education.

Ministry of Educational. (2007). Learning Guidelines for Cognitie Development Field. Jakarta: Ministry of Education.

Piaget, J., \& Inhelder, B. (1969). The Psychology of The Child. New York: Basic Books.

Sultan, Rofiuddin, A., Nurhadi, \& Priyatni, E.T. (2017). The effect of the critical literacy approach on pre-service language teachers' critical reading skills. Eurasian Journal of Educational Research, 71(3), 159-174, doi: 10.14689/ejer.2017.71.

Sultan, Rofiuddin, A., Nurhadi,\& Priyatni, E.T. (2018). Development of mass media textbased instructional materials to improve critical reading skills of university students. Pedagogika, 131(3), 26-47, doi: 10.15823/p.2018.32.

Walker, S.P. (2010). Commentary: Early stimulation and child development. International Journal of Epidemiology, 39(1), 294-296. https://doi.org/10.1093/ije/dyp316 
Walker, S.P., Wachs, T.D., Gardner, J.M., Lozoff, B., \& al, et. (2007). Child development in developing countries 2: Child development: risk factors for adverse outcomes in developing countries. The Lancet; London, 369(9556), 145-157.

Zeman, J., Cassano, M., Perry-Parrish, C., \& Stegall, S. (2006). Emotion Regulation in Children and Adolescents: Journal of Developmental \& Behavioral Pediatrics, 27(2), 155-168. https://doi.org/10.1097/00004703-200604000-00014

Zheng, Y., Rijsdijk, F., \& Arden, R. (2018). Differential environmental influences on the development of cognitive abilities during childhood. Intelligence, 66, 72-78. https://doi. org/10.1016/j.intell.2017.11.005 